\title{
APLIKASI HISTOGRAM UNTUK ANALISIS VARIABILITAS TEMPORAL DAN SPASIAL HUJAN BULANAN: STUDI DI WILAYAH UPT PSDA DI PASURUAN JAWA TIMUR
}

\author{
Dimas Ghufron Ash Shiddiq, Indarto, Sri Wahyuningsih, dan Askin \\ Program Studi Teknik Pertanian - Fakultas Teknologi Pertanian - Universitas Jember \\ E-mail: indarto.ftp@unej.ac.id
}

\begin{abstract}
ABSTRAK
Penelitian ini bertujuan untuk menganalisis variabilitas hujan bulanan di wilayah UPT PSDA di Pasuruan. Wilayah studi mencakup kabupaten Probolinggo, Kota Probolinggo, Kabupaten Pasuruan dan Kota Pasuruan di Jawa Timur. Data hujan harian dari 93 stasiun, dengan panjang rekaman data dari tahun 1980 sampai dengan 2015 digunakan sebagai input utama. Tahap penelitian mencakup: (1) pra-pengolahan data, (2) analisis variabilitas temporal, (3) Analisis variabilitas spasial, (4) interpolasi dan pembuatan peta tematik dan (5) interpretasi. Data hujan bulanan diperoleh dari penjumlahan hujan harian. Pra-pengolahan data dilakukan menggunakan excel. Data hujan bulanan ditabulasi selama 35 tahun periode rekaman data. Selanjutnya, metode interpolasi IDW digunakan untuk membuat berbagai peta tematik hujan. Penelitian ini menghasilkan deskripsi variabilitas spasial dan temporal hujan per sub-wilayah dan berbagai peta tematik terkait dengan karakteristik spasial hujan di wilayah tersebut. Hujan bulanan rerata di wilayah tersebut $152 \mathrm{~mm} /$ bulan. Hujan bulanan maksimum $798 \mathrm{~mm}$ per bulan. Kata kunci — histogram, hujan, spasial, temporal, spasial, variabilitas
\end{abstract}

\section{PENDAHULUAN}

Hujan merupakan fenomena alam yang bervariasi terhadap ruang dan waktu. Variabilitas hujan terhadap ruang sering disebut sebagai variabilitas spasial. Variabilitas terhadap waktu disebut sebagai variabilitas temporal. Pemahaman terhadap bagaimana variabilitas spasial dan temporal (spasiotemporal) curah hujan pada suatu wilayah sangat diperlukan dalam rangka pengelolan sumberdaya air, penjawalan musim tanam, perencanaan kebutuhan dan ketersediaan air. Analisis variabilitas spasial hujan bertujuan untuk memahami dan mengambarkan bagaimana hujan terdistribusi dalam suatu wilayah tertentu. Variabilitas spasial dapat ditunjukkan oleh perbedaan hujan yang diterima oleh subwilayah tertentu pada interval waktu tahunan, bulanan, atau harian. Analisis variabilitas temporal dapat digunakan untuk menggambarkan variasi atau fluktuasi hujan yang jatuh pada wilayah tertentu dalam suatu rentang waktu.

Kehadiran sistem informasi geografis dan teknologi pemetaan memungkinkan kita untuk dapat menggambarkan variabilitas spasial dan temporal hujan pada suatu wilayah. Analisis variabilitas spasial hujan sudah umum dilakukan pada banyak tempat di berbagai belahan dunia untuk berbagai keperluan dan menggunakan berbagai metode. Karena sifat pengukuran hujan adalah pengukuran pada titik tertentu, sementara peta distribusi spasial yang menjelaskan fenomena tersebut harus terdisribusi dalam lingkup wilayah tertentu, maka dapat dilakukan berbagai cara interpolasi dari titik menjadi luasan. Interpolasi data titik pengukuran menjadi peta hujan wilayah dapat dilakukan dengan metode : poligon thiessen, metode spline, metode kriging, metode IDW atau metode lainnya.

Analisis pendahuluan dan pemetaan variabilitas hujan di Jawa Timur misalnya dijumpai di dalam tulisan Indarto dan Boedi (2011, 2013ab). Penelitian terdahulu menggambarkan variabilitas spasial hujan per wilayah provinsi Jawa Timur untuk periode sebelum tahun 2010. Artikel ini memaparkan hasil analisis variabilitas spasial dan variabilitas temporal hujan bulanan pada wilayah yang lebih sempit, menggunakan data yang lebih lengkap. Kelengkapan data ditunjukkan oleh panjang rekaman data harian yang digunakan dan kerapatan stasiun hujan per sub-wilayah.

Tujuan penelitian ini adalah untuk menganalisis variabilitas spasial dan variabilitas temporal hujan bulanan. Variabilitas temporal ditunjukan dengan variasi jumlah hujan per bulan yang dinyatakan dengan diagram batang, analisis distibusi frekuensi dan kecenderungan hujan bulanan menggunakan regresi linear. Variabilitas spasial ditunjukan dengan distribusi data secara spasial melalui histogram dan normal QQ-plot. Peta tematik yang dihasilkan dalam penelitian ini dapat dimanfaatkan dalam perencanaan, monitoring dan evaluasi pengelolaan sumber daya air di wilayah tersebut. 


\section{METODOLOGI PENELITIAN}

\section{A. Lokasi dan Waktu Penelitian}

Penelitian ini dilaksanakan pada bulan Februari sampai dengan Oktober 2017. Dalam konteks pengelolaan sumberdaya air, wilayah provinsi Jawa Timur dibagi ke dalam 9 sub-wilayah yang dikenal dengan UPT PSDA (Unit Pelaksana Teknis - Pengelolaan Sumberdaya Air). Wilayah UPT PSDA Pasuruan merupakan 1 dari 9 wilayah UPT yang ada di Jawa Timur. Lokasi penelitian di wilayah kerja UPT PSDA di Pasuruan.

Wilayah kerja UPT PSDA di Pasuruan mencakup wilayah administrasi: Kota Pasuruan, Kabupaten Pasuruan, Kota Probolinggo, Kabupaten Probolinggo, dan Kecamatan Lawang (Gambar 1). Sebanyak, 93 lokasi stasiun digunakan dalam penelitian ini. Pengolahan data dilaksanakan di Laboraturium Teknik Pengendalian dan Konservasi Lingkungan (TPKL) Jurusan Teknik Pertanian FTP - Universitas Jember.

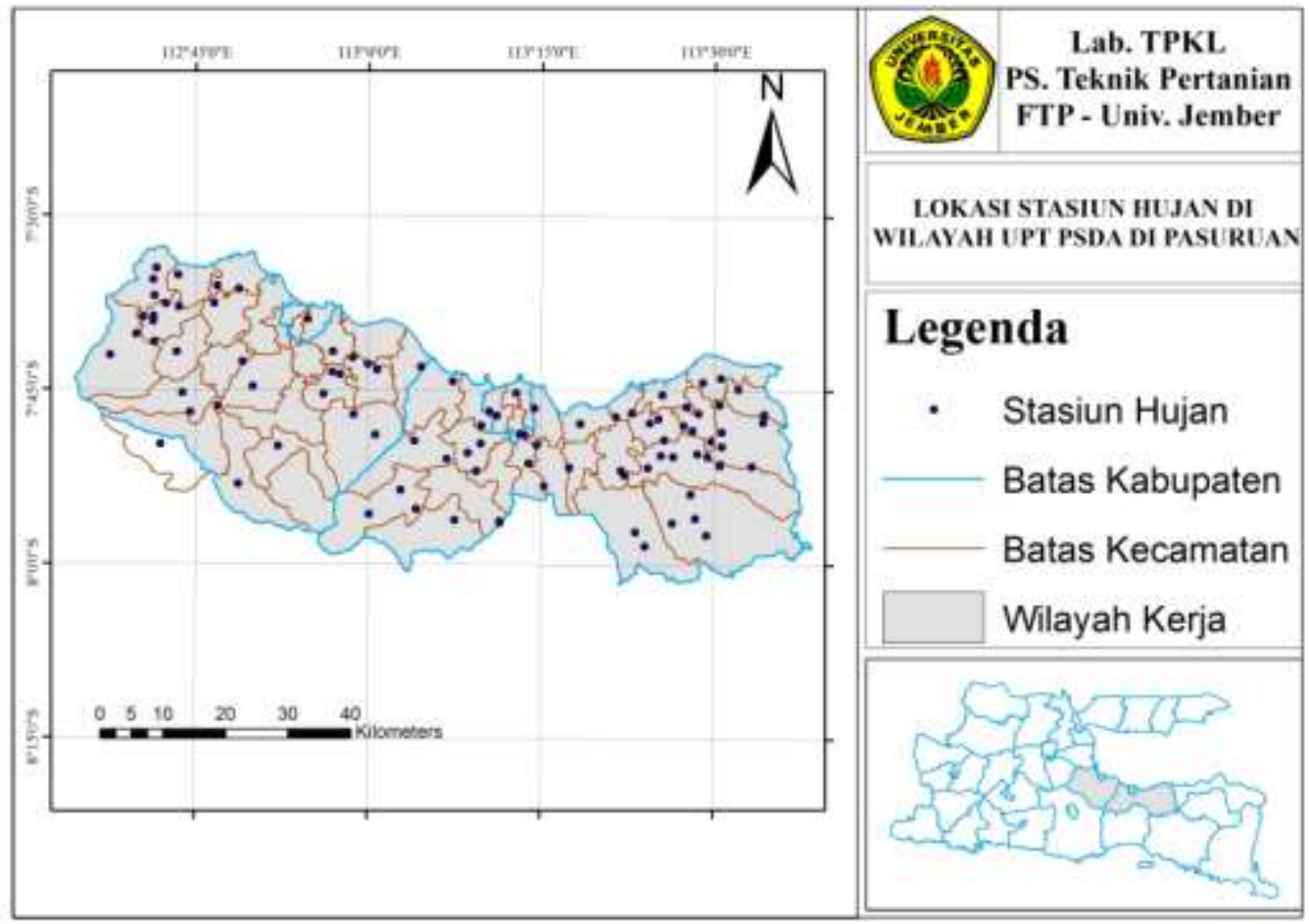

Gambar 1. Lokasi Stasiun Hujan yang Digunakan

\section{B. Bahan dan Alat}

Bahan utama untuk penelitian ini adalah data hujan harian yang diperoleh dari 93 stasiun. Periode rekaman hujan harian mulai dari tahun 1980 - 2015 (35 tahun). Hujan bulanan (HB) didefinisikan sebagai jumlah kumulatif hujan yang terukur pada setiap lokasi stasiun pengukuran hujan. Selanjutnya, hujan bulan januari (Hjan) ditentukan dari rerata nilai hujan di bulan januari selama 35 tahun. Hujan bulan januari maksimal (HjanMaks) adalah nilai hujan bulan januari yang paling maksimal selama 35 tahun. Hujan rerata bulanan (HRB) atau hujan bulanan rerata (HBR) ditentukan dari rerata hujan bulanan selama periode rekaman yang ada ( selama 35 tahun, dari 1980 sd 2015) pada lokasi stasiun pengukuran hujan. HRB menghitung semua hujan yang jatuh pada setiap bulan, dari $1980 \mathrm{sd}$ 2015 (jadi nilai rerata dari $35 \times 12=420$ kejadian hujan). Jadi setiap 1 stasiun memiliki 1 data HRB/HBR. Hujan bulanan Maksimal (HBMaks) dihitung dari 432 kejadain hujan bulanan yang paling maksimal. Setiap stasiun memiliki 1 data HBMaks. Selanjutnya, dau variabel hujan yaitu: HRB/HBR dan Hbmaks digunakan untuk menggambarkan variabilitas spaso-temporal hujan. Peralatan yang digunakan untuk analisis mencakup: (1) PC, (2) perangkat lunak Excel/OO-Calc dan (3) perangkat lunak GIS untuk analisis ESDA dan pembuatan peta tematik. 


\section{Prosedur Penelitian}

Tahapan penelitian yang meliputi: (1) inventarisasi data, (2) analisis variabilitas temporal, (3) analysis varibilitas spasial, dan (4) interpolasi dan pembuatan peta tematik.

\section{a. Inventrasi dan Format Data}

Data hujan yang digunakan dalam penelitian ini merupakan data hujan harian yang diambil dari alat ukur yang ada di wilayah kerja UPT PSDA di Pasuruan. Panjang periode rekaman dari tahun 1980 - 2015. Koordinat lokasi dan ketinggian lokasi stasiun hujan juga digunakan sebagai input ke dalam software GIS. Setelah proses rekap dan verifikasi data selesai, data hujan selanjutnya direkap dalam (Tabel 1) untuk input ke dalam perangkat lunak GIS.

Tabel 1. Contoh Format Data ke Dalam Excel

\begin{tabular}{lcccccccc}
\hline Nama Stasiun & $\mathrm{mT}$ & $\mathrm{mU}$ & $\begin{array}{c}\text { El } \\
(\mathrm{m})\end{array}$ & $\begin{array}{c}\text { Pr } \\
\text { (tahun) }\end{array}$ & Hthn_Max & HThn_rrt & HRB & HB_Maks \\
\hline Adiboyo & 760007 & 9138450 & 11 & 29 & 1995 & 1234,3 & 102,9 & 638 \\
Arah Makam & 774657 & 9132016 & 190 & 29 & 4449 & 2568,0 & 214,0 & 1115 \\
Asemjajar & 783667 & 9138745 & 135 & 30 & 2998 & 1670,4 & 139,2 & 833 \\
Bago & 775218 & 9134509 & 140 & 30 & 3102 & 1999,7 & 166,6 & 832 \\
Bantaran & 737688 & 9129928 & 87 & 30 & 2691 & 1640,5 & 136,7 & 842 \\
Banyuanyar & 752564 & 9130402 & 89 & 29 & 2660 & 1624,8 & 135,4 & 750 \\
\hline
\end{tabular}

Identifikasi untuk tiap kolom (Tabel 1) adalah sebagai berikut: kolom 1 adalah nama stasiun; kolom ke 2 dan 3 adalah adalah $\mathrm{mT}$ (meter Timur) dan $\mathrm{mU}$ (mater Utara) untuk sistem proyeksi UTM Zone 49S WGS84; kolom ke 4 adalah El (m) yang menunjukkan ketinggian lokasi stasiun hujan (satuan meter); kolom ke 5 adalah Pr merupakan periode rekaman data dalam satuan tahun; kolom ke 6 (Hthn Max) adalah hujan tahunan maksimal; kolom ke 7 (HThn rrt) adalah hujan tahunan rata-rata; kolom ke 8 (HRB) adalah hujan rerata bulanan; kolom ke 9 (HB_Maks) adalah hujan bulanan maksimal. Seterusnya format excel dapat diperpanjang sesuai dengan variabel terkait dengan hujan yang akan dianalisis.

\section{b. Analisis variabilitas temporal}

Variabiitas hujan terhadap rentang waktu ditampilkan secara kualitatif dengan menggunakan histogram, distribusi frekuensi hujan bulanan dan analisi regresi. Distribusi hujan per bulan digunakan untuk mengambarkan seberapa besar hujan yang jatuh setiap bulannya. Distribusi frekuensi menggambarkan sebarapa sering kejadian hujan dengan tebal hujan tertentu terjadi dalam kurun 35 tahun tersebut. Analisis variabilitas temporal juga dilakukan dengan melukan regresi linear dan moving average untuk menyatakan secara sederhana, ada dan tidaknya kecenderungan hujan selama periode 35 tahun tersebut.

\section{c. Analisis variabilitas spasial}

ESDA atau (Exploratory Spatial Data Analysis) digunakan untuk menganalisis secara statistik: distribusi, sebaran dan kecenderungan data. Ada banyak tool yang dapat digunakan di dalam ESDA (Histogram, Voronoi, Normal QQ-Plot, Thiesen Polygon, dll). ESDA dapat digunakan untuk melihat variabilitas data secara spasial yang ditunjukkan oleh histogram distribusi frekuensi, Voronoi-Map, dan QQ-Plot (Johnson et al., 2001; Indarto, 2011, 2013ab). Pada tulisan analisis variabilitas spasial data ditunjukkan melalui Histogram dan Normal QQ Plot.

\section{d. Interpolasi dan pembuatan peta tematik}

Metode interpolasi berbasis IDW (Inverse Distance Weighting) (Johnson et al., 2001; Indarto, 2011, 2013ab) digunakan untuk membuat peta tematik distribusi spasial hujan bulanan. Hasil akhir analisis adalah peta distribusi spasial hujan bulanan. 


\section{HASIL DAN PEMBAHASAN}

\section{A. Variabilitas Temporal Hujan}

Pada penelitian ini variabilitas hujan bulanan terhadap waktu diilustrasikan menggunakan diagram batang hujan per bulan (diagram batang hujan bulanan), histrogram distribusi frekuensi dan analisis kecenderungan menggunakan regresi linear.

\section{B. Diagram Batang Hujan Bulanan Rerata}

Diagram hujan bulanan rerata (Gambar 2) menyatakan distribusi hujan yang jatuh per bulan (mulai Januari, Februari, Maret, April, sampai dengan November, Desember). Pada Gambar 2, ditampilkan nilai rerata hujan yang jatuh per bulan atau hujan bulanan rerata (HBR) selama 36 tahun untuk ke 8 lokasi stasiun hujan. Gambar (2) secara sekilas menampilkan adanya perbedaan jumlah hujan yang jatuh pada tiap bulannya. Hujan yang diterima antara satu stasiun dan stasiun yang lain relatif berbeda. Musim kering dengan curah hujan $<100 \mathrm{~mm} /$ bulan dimulai pada bulan Mei atau Juni dan berakhir pada bulan Oktober atau November. Musim hujan dengan curah hujan $>100 \mathrm{~mm} / \mathrm{bulan}$ dimulai november atau desember. Panjang dan pendeknya musim kemarau berbeda untuk ketinggian lokasi stasiun hujan yang berbeda.

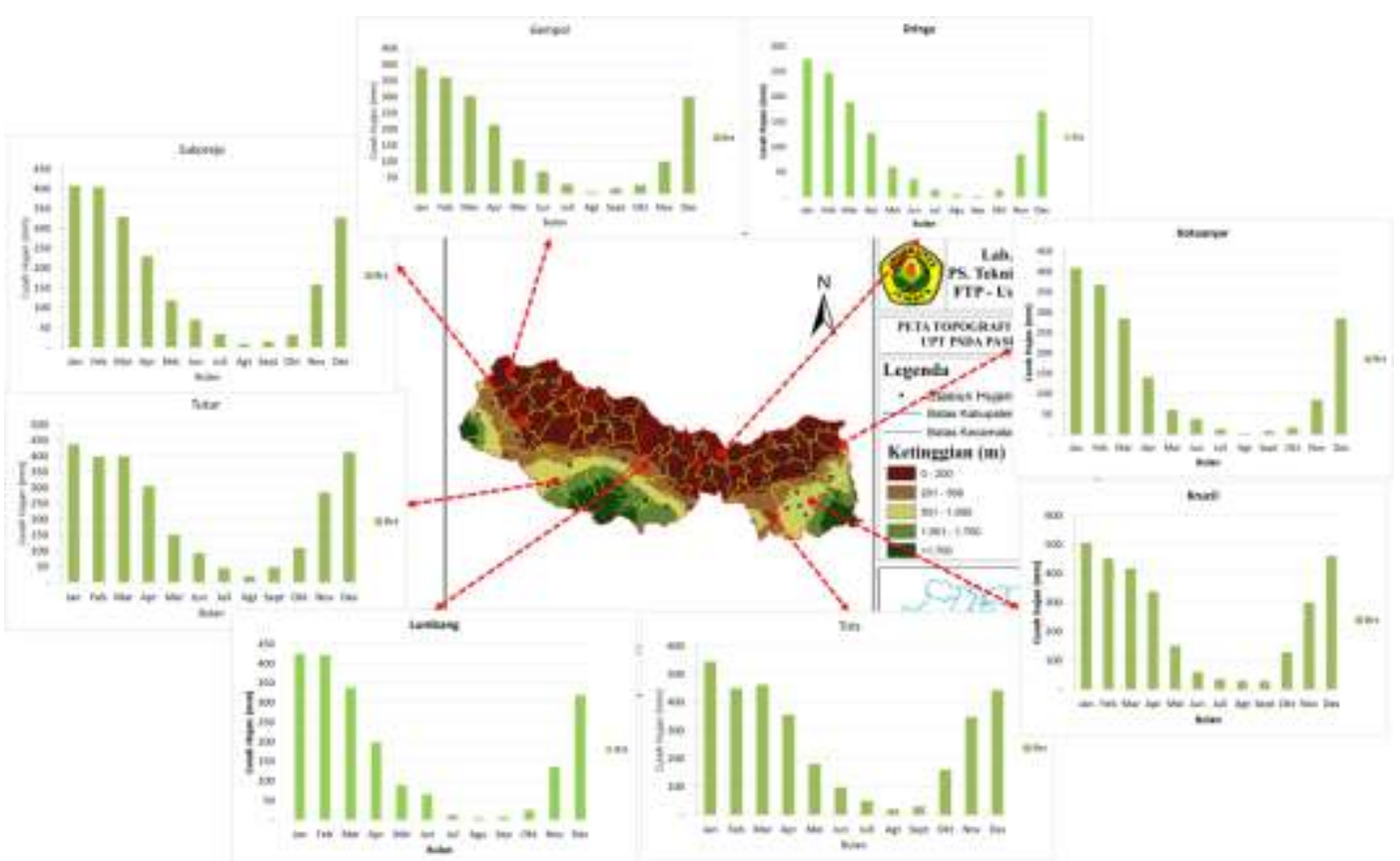

Gambar 2. Diagram Batang Hujan Bulanan Rerata (HBR) pada 8 Lokasi Stasiun Hujan

Pada Gambar 3 ditampilkan diagram batang HBR yang terjadi pada wilayah pantai dengan ketinggian lokasi stasiun hujan 0 sd $200 \mathrm{~m}$ dpl. Bulan kering, dimana jumlah hujan di bawah $100 \mathrm{~mm}$ per bulan terjadi mulai bulan Mei sampai dengan November atau bulan kering $=7$ bulan .

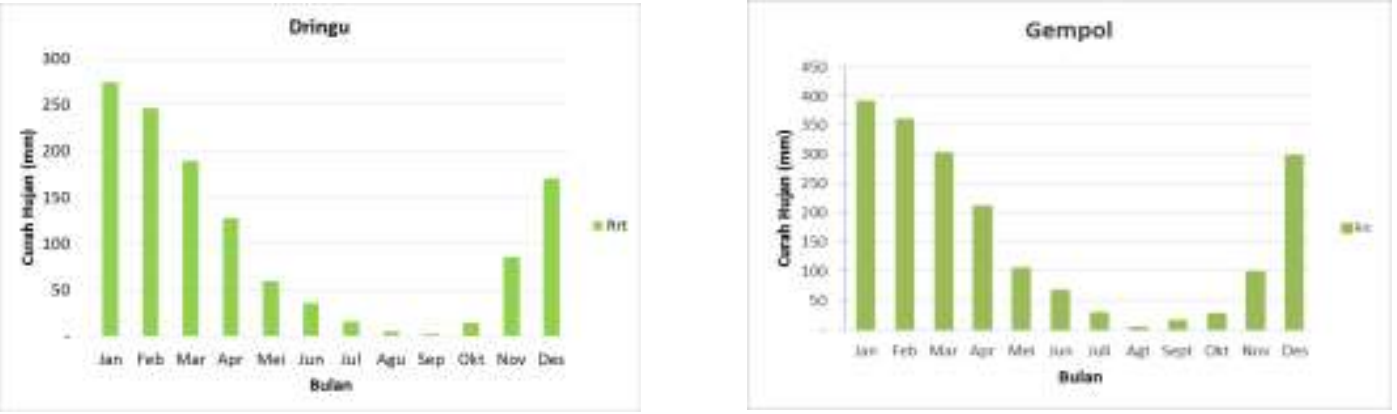

Gambar 3. Diagram Batang HBR untuk Stasiun di Wilayah Pantai, Ketinggian $<200 \mathrm{~m}$ dpl 
Pada Gambar 4, ditampilkan hujan bulanan dua stasiun hujan pada ketinggian di atas nya (antara $200 \mathrm{sd} 500 \mathrm{mdpl}$ ). Musim kering, yang ditnjukkan oleh hujan di bawah $100 \mathrm{~mm}$ per bulan, terjadi antara Mei sampai dengan Oktober atau bulan kering $=6$ bulan.
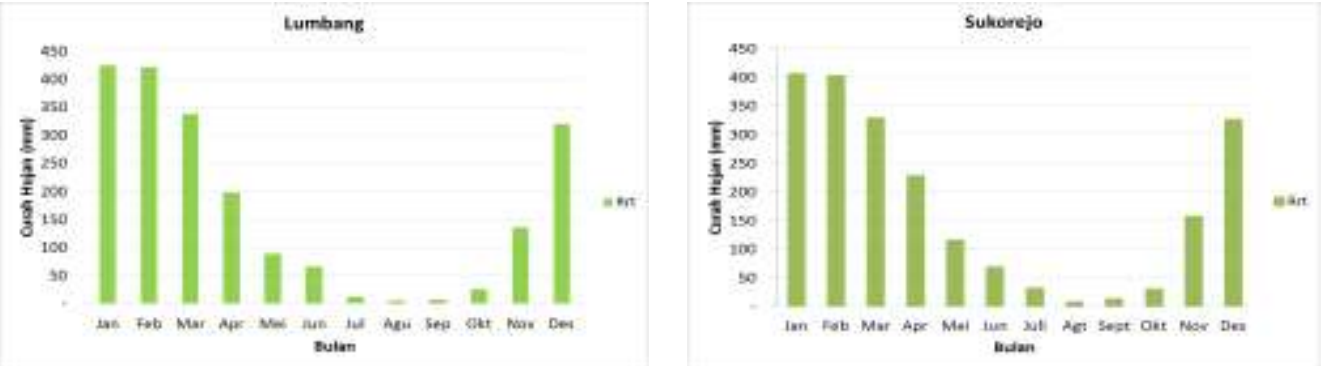

Gambar 4. Diagram Batang HBR untuk Stasiun dengan Ketinggian 201 sd 500 m dpl

Pada Gambar 5, ditampilkan hujan bulanan tiga stasiun hujan pada ketinggian di atas $>500$ mdpl. Musim kering, yang ditnjukkan oleh hujan di bawah $100 \mathrm{~mm}$ per bulan, terjadi antara Juni sampai dengan September atau bulan kering $=4$ bulan.

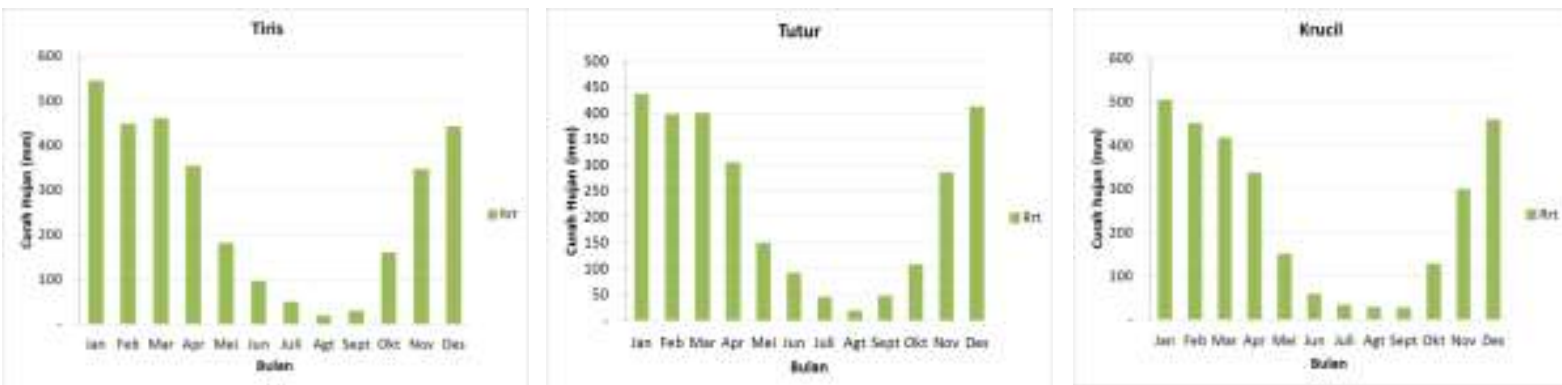

Gambar 5. Diagram Batang HBR untuk Stasiun dengan Ketinggian $>500 \mathrm{~m} \mathrm{dpl}$

\section{Distribusi Frekuensi Hujan Bulanan (HB)}

Variabilitas hujan bulanan (HB) terhadap waktu juga dapat dilihat dengan histogram distribusi frekuensi (Gambar 6). Distribusi frekuensi menyatakan jumlah kejadian HB yang diklasifikasikan ke dalam interval kelas tertentu. Frekuensi menyatakan banyak-nya bulan dimana hujan yang jatuh pada bulan tersebut berada pada kelas interval yang dimaksud.

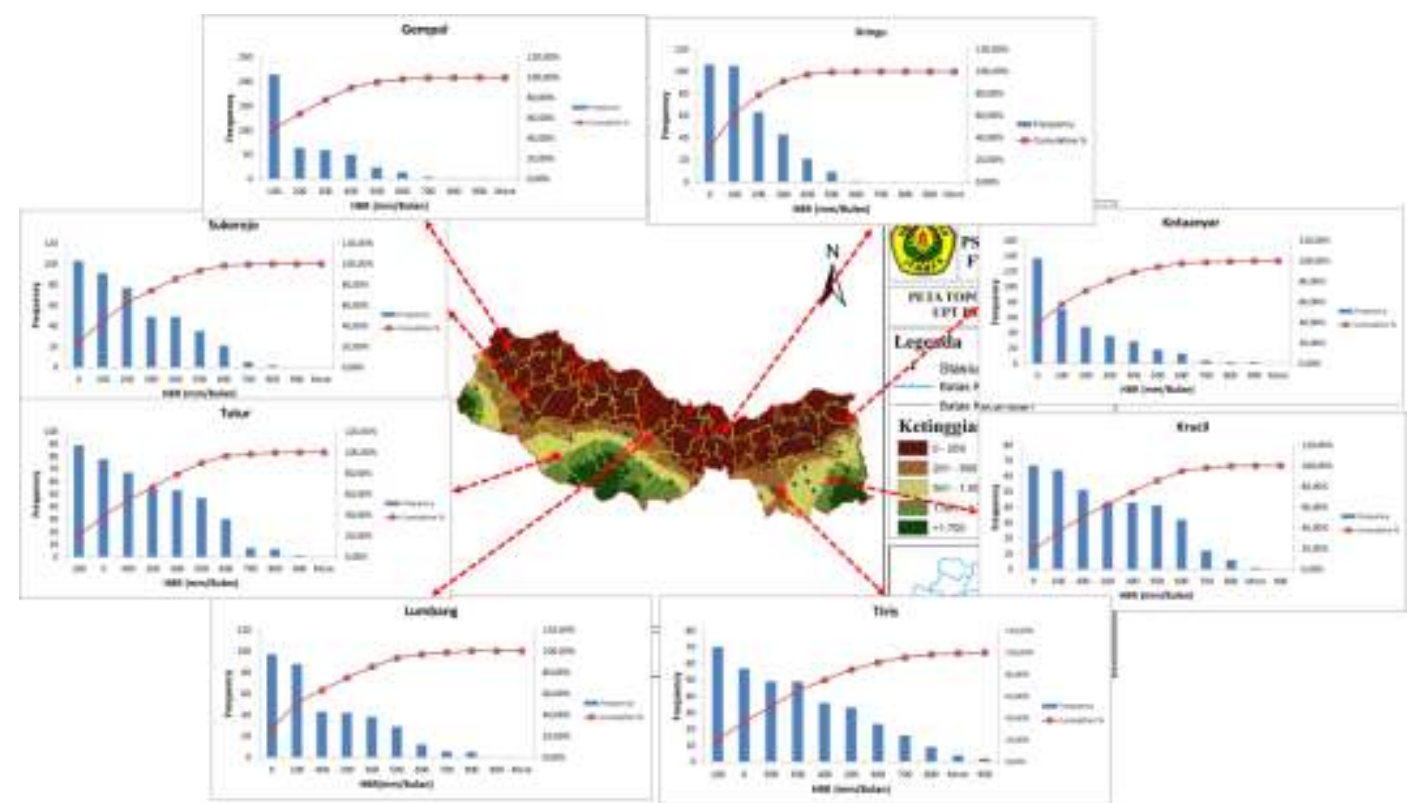

Gambar 6. Distirbusi Frekuensi Hujan Bulanan pada 8 Lokasi Stasiun Hujan 
Pada Gambar 7, ditampilkan distribusi frekuensi HB pada dua stasiun ( Dringu dan Gempol), di mana ketinggian lokasi stasiun hujan tersebut $<200 \mathrm{~m}$ dpl. Total kejadian HB ada sekitar $(12 \times 36)$ $=432$ data. Misalnya, pada stasiun Gempol (Gambar 7) ada 200 bulan /432 bulan di mana hujan yang jatuh kurang dari $100 \mathrm{~mm} /$ bulan atau $46 \%$ kejadian $\mathrm{HB}$.
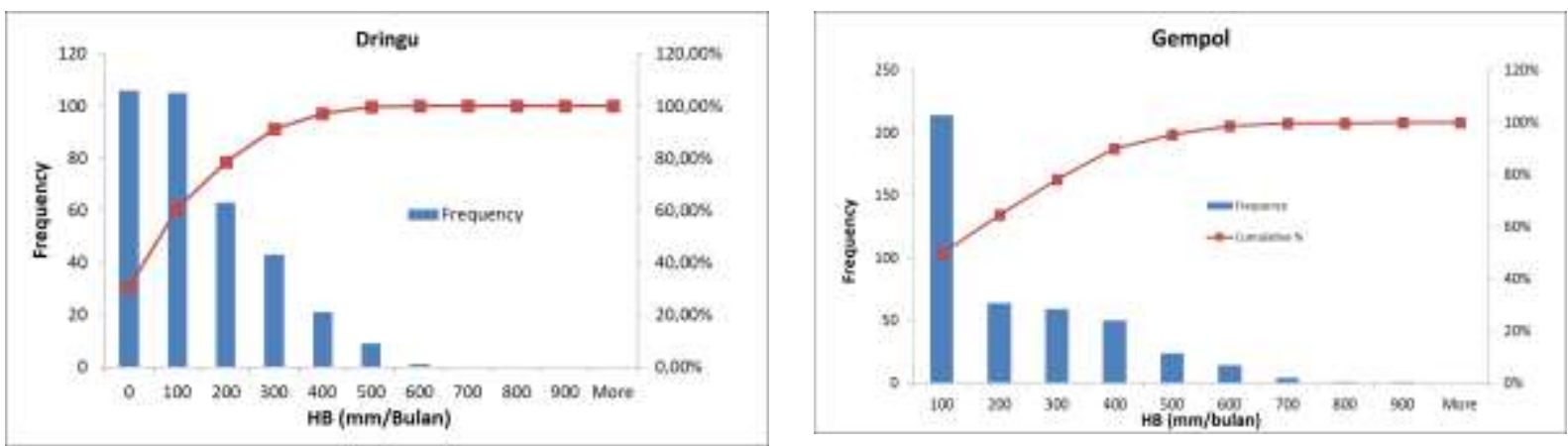

Gambar 7. Distribusi Frekuensi Hujan Bulanan pada Lokasi Stasiun (Dringu dan Gempol) dengan Ketinggian 0 sd 200m dpl

Bentuk distribusi frekuensi HB pada stasiun Gempol dan Dringu relatif identik. Bentuk distibusi tidak mengikuti distribusi normal, tetapi cenderung ke menceng ke kiri, dimana frekuensi kejadian lebih didominasi oleh HB rendah $(<100 \mathrm{~mm} /$ bulan). Nilai rerata HB pada stasiun Dringu selama 36 tahun $=102 \mathrm{~mm} /$ bulan dan nilai maksimum $=544 \mathrm{~mm} /$ bulan. Selanjutnya, nilai skewness $=$ 1,$2 ;$ kurtosis $=0,8 ;$ standard deviasi $=121,3$. Sedangkan untuk stasiun Gempol, nilai rerata $\mathrm{HB}=157$ $\mathrm{mm}$ per bulan, nilai maksimum $\mathrm{HB}=840 \mathrm{~mm} /$ bulan. Nilai skewness $=1,1$; kurtosis $=0,7$ dan standard deviasi $=171,3$. Kedua distribusi frekuensi HB relatif sama yang ditunjukkan oleh nilai skewness dan kurtosis nya.

Selanjutnya pada Gambar 8, ditampilkan nilai HB pada stasiun Lumbang dan Sukerjo, pada ketinggian $201 \mathrm{sd} \mathrm{500m} \mathrm{dpl.} \mathrm{Frekuensi} \mathrm{kejadian} \mathrm{hujan}<100 \mathrm{~mm}$ per bulan pada ke dua stasiun hujan relatif lebih kecil ( $<200$ kejadian). Distibusi jumlah HB per kelas semakin tumpul di sisi kiri atau bergeser ke arah kanan.

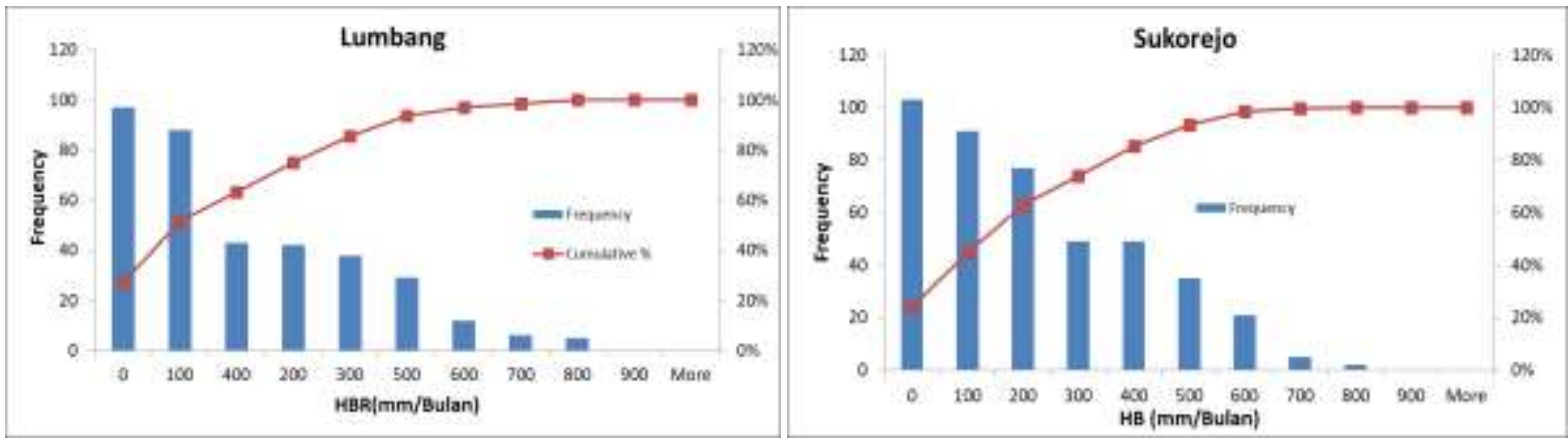

Gambar 8. Distribusi Frekuensi Hujan Bulanan pada Lokasi Stasiun (Lumbang dan Sukorejo), pada ketinggian $201 \mathrm{sd} 500 \mathrm{~m}$ dpl

Selanjutnya, pada stasiun Lumbang, nilai rerata $\mathrm{HB}=169 \mathrm{~mm} / \mathrm{bulan}$ dan nilai maksimum HB $=779 \mathrm{~mm} /$ bulan. Nilai skewness $=1,0 ;$ kurtosis $=0,1 ;$ dan standar deviasi $=189$. Sedangkan untuk stasiun Sukorejo, nilai rerata $\mathrm{HB}=175 \mathrm{~mm} /$ bulan dan nilai maksimum $\mathrm{HB}=727 \mathrm{~mm} /$ bulan. Nilai skewness $=0,9$; kurtosis $=-0,3$ dan std deviasi $=179$. Uraian di atas menunjukkan bagaiamana distribusi frekuensi dapat digunakan untuk melihat sebaran hujan bulanan (HB) per kelas selama kurun waktu tertentu ( 1980 sd 2015).

\section{Variabilitas Spasial Hujan Bulanan}

a. Analisis ESDA: Histogram Hujan Bulanan Rerata (HBR)

Dalam konteks ini hujan bulanan rerata (HBR) dihitung dari rerata jumlah hujan yang jatuh per bulan, dari bulan Januari sd Desember. Hujan yang jatuh pada lokasi pengukuran 
(stasiun hujan) dihitung per bulan dari Januari sd Desember. Selanjutnya, HBR dihitung dari nilai rerata semua data pada tahun yang tersedia (yaitu dari: 1980 - 2015). Nilai HBR per stasiun selanjutnya dianalisis menggunakan tool histogram pada ArcGIS Geostatistical Analysist dan dihasilkan histogram hujan bulanan rerata (HBR) untuk ke 93 stasiun di wilayah studi (Gambar 9).

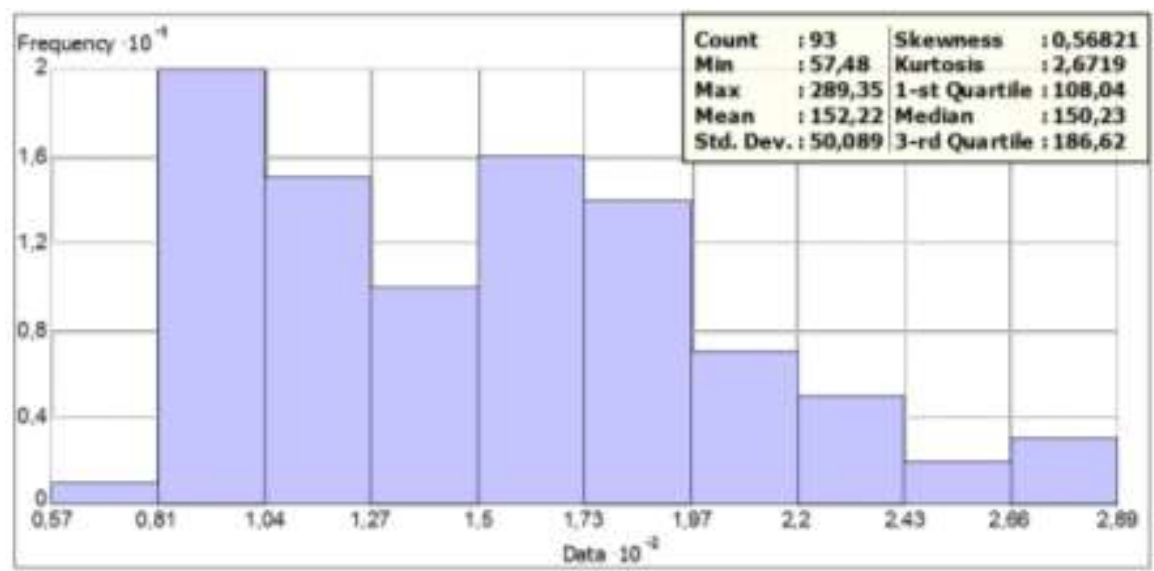

Gambar 9. Histogram Hujan Bulanan Rerata (HBR)

Histogram (Gambar 9) menunjukan ringkasan statistik yang didapatkan, yaitu: nilai $\mathrm{HBR}$ minimal $=57,48 \mathrm{~mm} /$ bulan, nilai HBR maksimal $=289,35 \mathrm{~mm} /$ bulan, dan nilai HBR rerata untuk semua stasiun pada wilayah tersebut $=152,22 \mathrm{~mm} /$ bulan. Nilai $\mathrm{HBR}=152,22$ $\mathrm{mm} /$ bulan menunjukan rerata hujan yang diterima per bulan untuk semua stasiun di wilayah tersebut (dari tahun 1980 sd 2015). Jumlah stasiun yang dianalisis (Count) $=93$ stasiun. Niai statistik lain yang ditampilkan adalah, standar deviasi (Std.Dev.) = 50,08; Koefisien kemencengan kurva histogram (skewness) $=0,56$; Koefisien keruncingan histogram (kurtosis) $=2,67$ dan nilai median $\mathrm{HBR}=150,23 \mathrm{~mm} / \mathrm{bulan}$.

Gambar 10 memperlihatkan histogram distribusi frekuensi dari stasiun hujan yang memiliki nilai HBR antara $57 \mathrm{sd} 127 \mathrm{~mm}$ per bulan, kelas frekuensi yang terseleksi terlihat pada gambar (10 kiri) sebagai bagian histogram yang berwarna biru. Distribusi spasial lokasi stasiun hujan yang memenuhi kriteria seleksi tersebut (HBR antara $57-127 \mathrm{~mm} / \mathrm{bulan}$ ) terlihat di peta pada gambar (10 kanan). Jumlah stasiun hujan dengan nilai tersebut (HBR antara 57 $127 \mathrm{~mm} /$ bulan $)=35$ stasiuan dan tersebar relatif di sepanjang garis pantai.

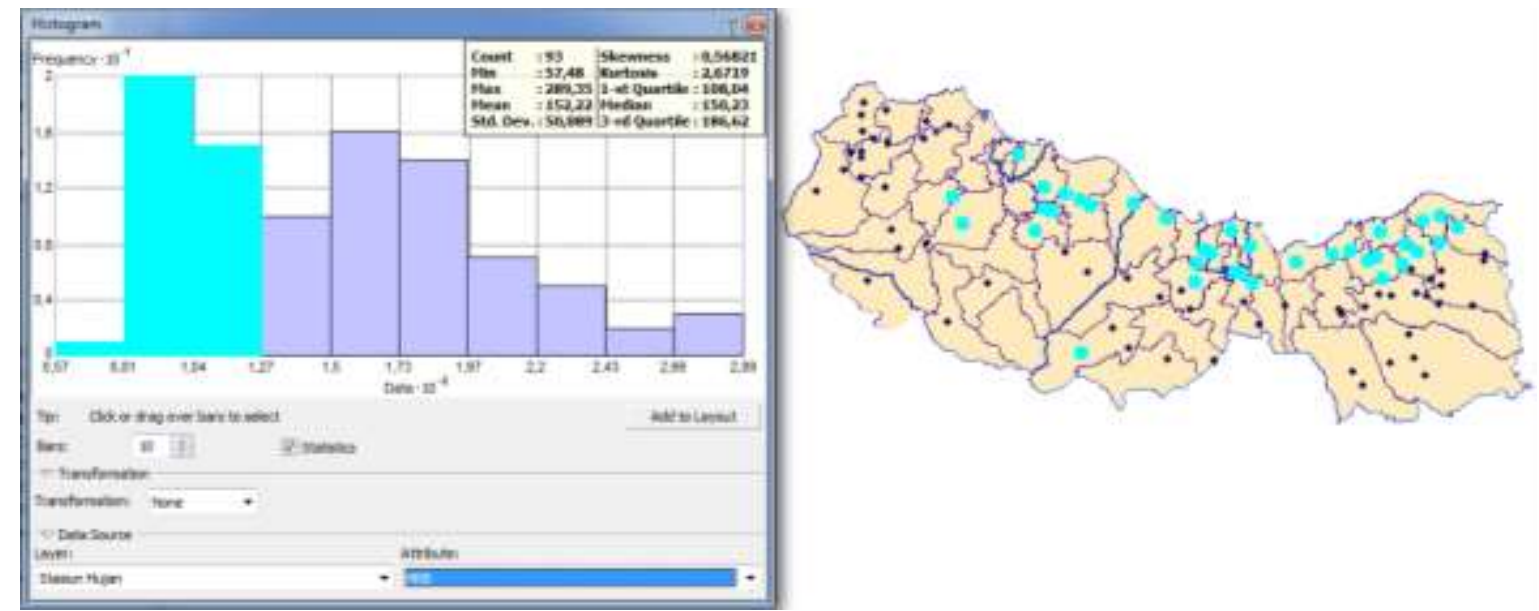

Gambar 10. Histogram (kiri) dan Distribusi Spasial Stasiun Hujan dengan Nilai HBR antara 57 - $127 \mathrm{~mm}$ 
Selanjutnya Gambar 11, menampilkan distribusi frekuensi dan sebaran lokasi stasiun hujan dengan nilai HBR antara $127-197 \mathrm{~mm} /$ bulan atau kelokpok stasiun yang menerima HBR pada kelas sedang. Ada sejumlah 40 stasiun hujan dengan sebaran lokasi stasiun hujan pada bagian tengah wilayah studi atau pada kisaran ketinggian $200 \mathrm{sd} 500 \mathrm{mdpl}$.

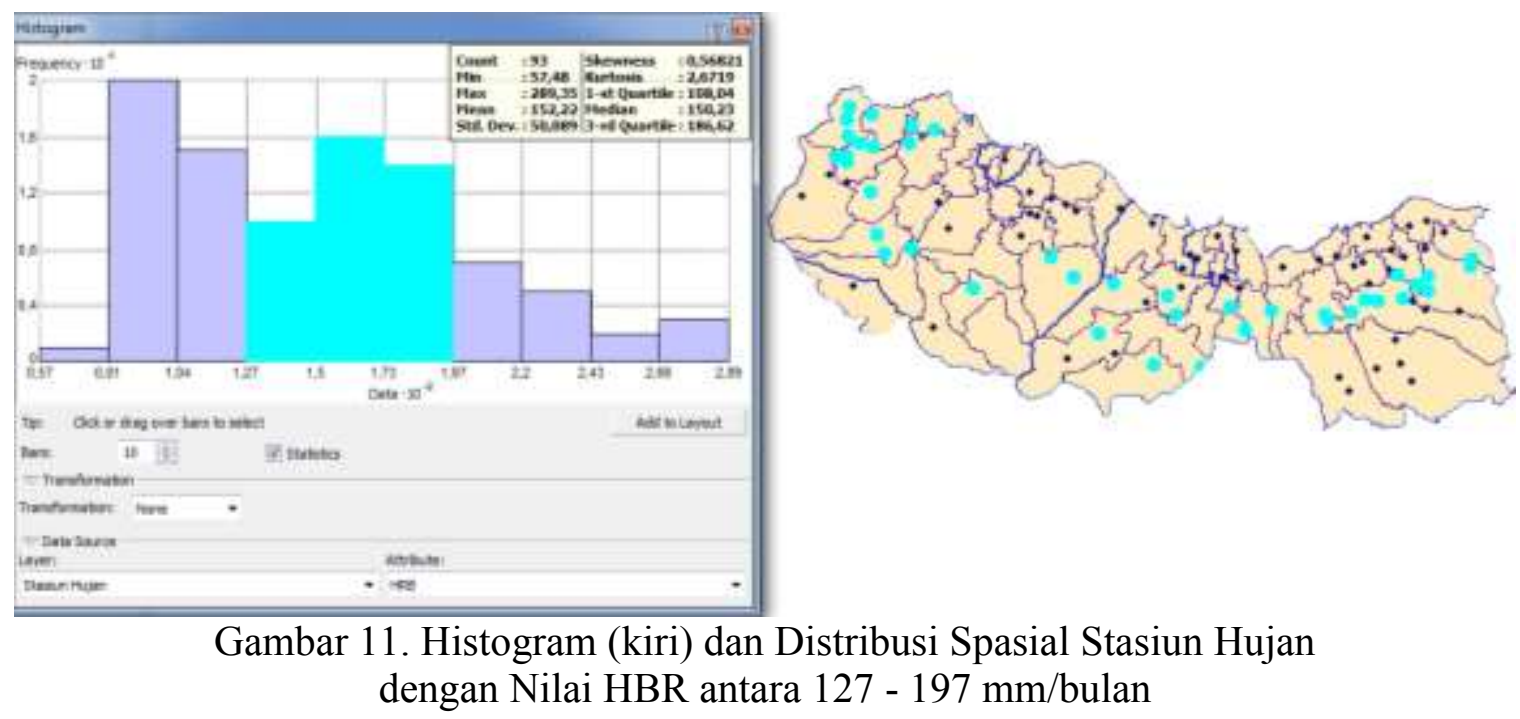

Selanjutnya Gambar 12 menampilkan histogram distribusi frekuensi dan sebaran spasial stasiun hujan yang memenuhi kriteria nilai HBR antara $197-289 \mathrm{~mm} / \mathrm{bulan}$. Stasiun yang masuk dalm kelas nilai HBR tinggi ini ada sejumlah 17 stasiun dan tersebar relatif pada sepanjang wilayah pegunungan di bagian selatan (dari timur ke barat).

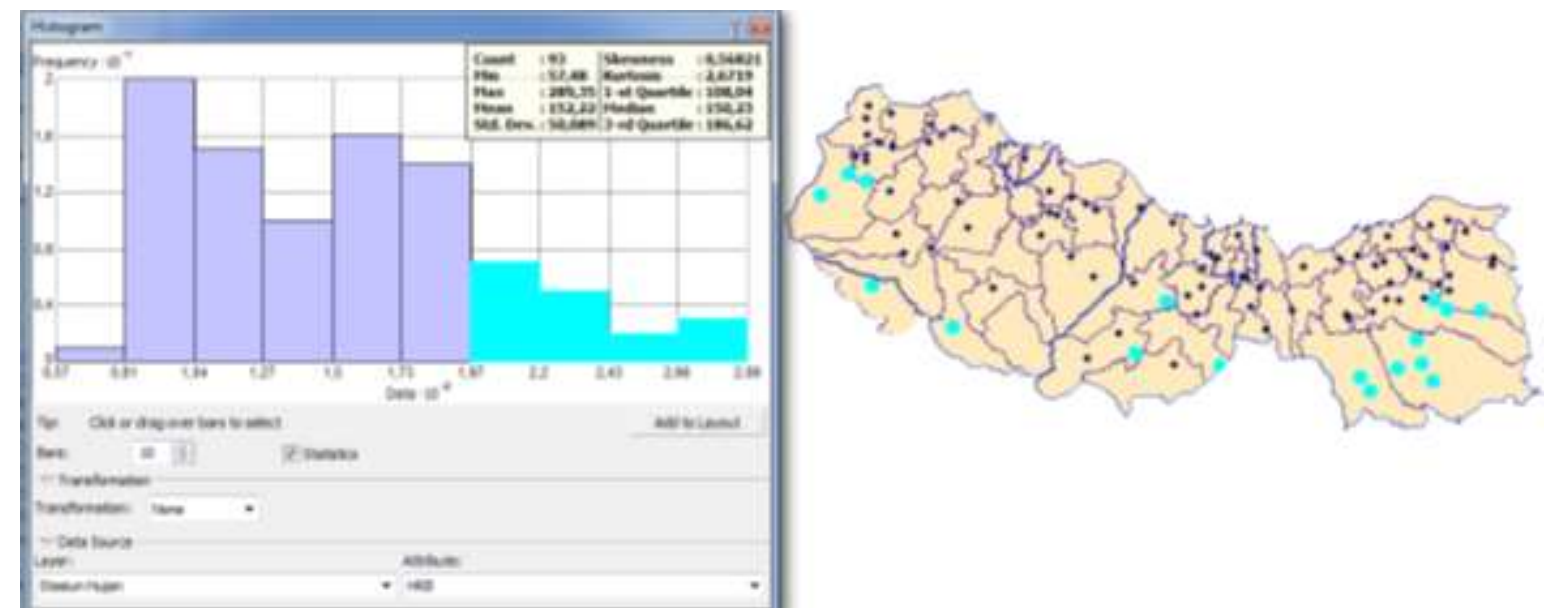

Gambar 12. Histogram (kiri) dan Distribusi Spasial Stasiun Hujan dengan Nilai HBR antara 197 - 289 mm/bulan

\section{b. Analisis ESDA: Histogram Hujan Bulanan Maksimal (HBMaks)}

Dalam konteks ini, HBMaks dicari dari nilai maksimal hujan yang jatuh setiap bulannya (dari bulan Januari sd Desember) dari semua data pada tahun yang tersedia (1980 2015). Nilai HBMaks (satu nilai per stasiun) selanjutnya dibandingkan antara stasiun satu dengan lainnya dan dianalisis menggunakan tool histogram. Gambar (13) menampilkan histogram distribusi frekuensi HBMaks untuk ke 93 stasiun di wilayah studi. 


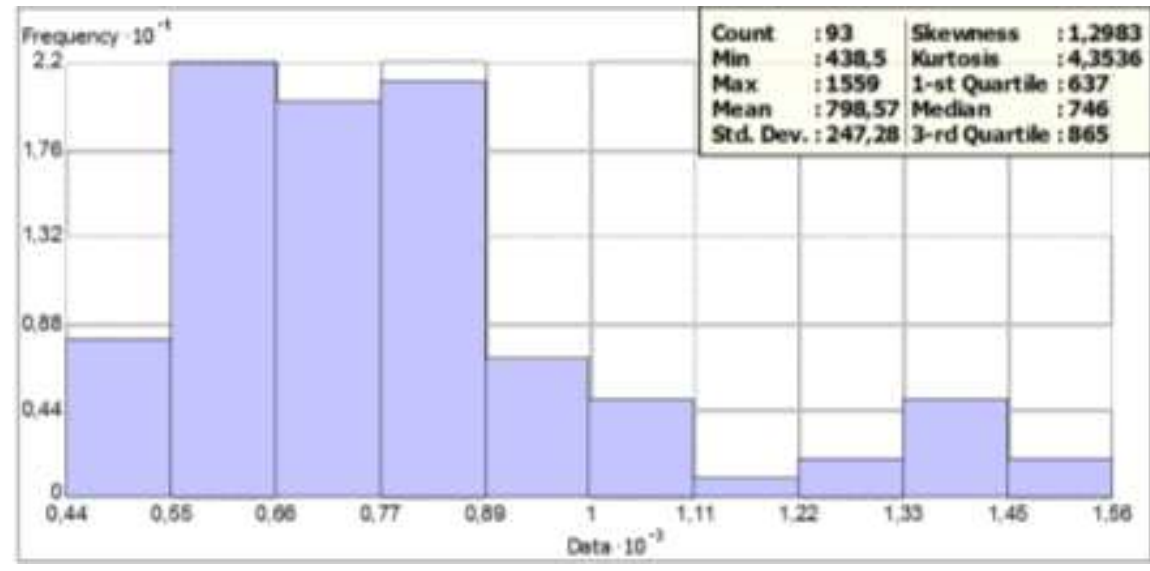

Gambar 13. Histogram Distribusi Frekuensi Hujan Bulanan Maksimal (HBMaks) dari 93 Stasiun Hujan

Histogram menunjukan jumlah stasiun yang digunakan (count) $=93$. Nilai HBMaks minimal $(\min )=438,5 \mathrm{~mm} /$ bulan. Nilai HBMaks maksimal $(\max )=1559 \mathrm{~mm} / \mathrm{bulan}$. Nilai HBMaks rerata untuk semua stasiun pada wilayah tersebut (Mean) $=798,57 \mathrm{~mm} / \mathrm{bulan}$. Histogram (Gambar 13) juga memuat nilai ringkasan statistik yaitu: Standar deviasi (Std.Dev) $=247,28$; koefisien kemencengan histogram (skewness) $=1,29$; koefisien kurtosis $=4,35$; kuantil 0,25 $\left(1^{\text {st }}\right.$ Quartile $)=637 \mathrm{~mm} /$ bulan ; Nilai median atau kuantil 0,50 $\left(2^{\text {nd }}\right.$ Quintile $)=746$ $\mathrm{mm} /$ bulan dan kuantil 0,75 ( $3^{\text {rd }}$ Quartile) $=865 \mathrm{~mm} /$ bulan. Bentuk distribusi dinyatakan dengan koefisien skewness dan kurtosis. Distribusi tergolong condong ke kiri dengan nilai skewness 1,29. Artinya jumlah stasiun dengan nilai HBmaks di bawah nilai HBMaks rerata, masih lebih banyak daripada jumlah stasiun dengan nilai HBMaks ekstrem tinggi.

Selanjutnya, Gambar (14) menampilkan histogram distribusi frekuensi dan distribusi spasial lokasi stasiun hujan dengan rentang nilai HBMaks antara $440-770 \mathrm{~mm} / \mathrm{bulan}$. Frekuensi yang didapatkan berjumlah $(8+22+20)=50$ stasiun hujan. Distribusi lokasi stasiun tersebut tersebar merata ke seluruh wilayah UPT.
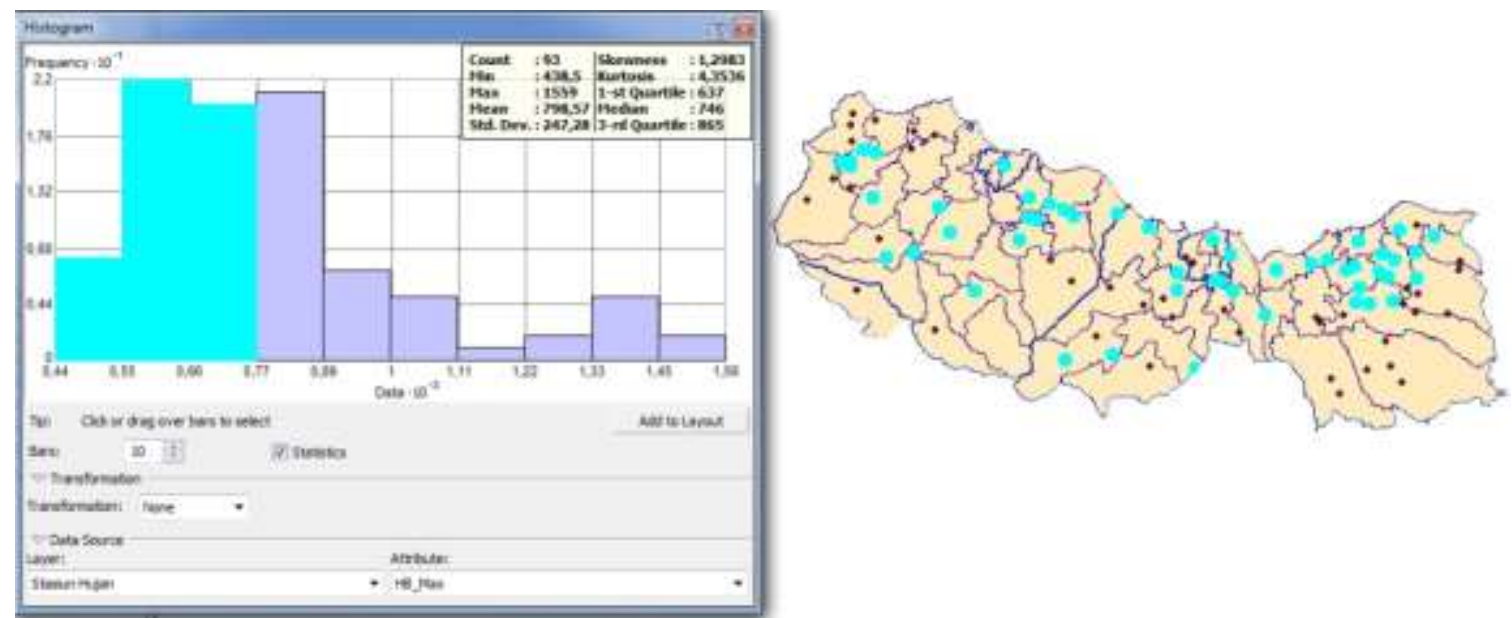

Gambar 14. Distribusi Spasial Curah Hujan Nilai 440 - 770 mm

Pada Gambar 15 ditampilkan distribusi frekuensi stasiun hujan dengan nilai HBMaks antara 770 - $1111 \mathrm{~mm} /$ bulan (ditampilkan dengan bagian histogram yang berwarna biru) pada gambar kiri. Jumlah stasiun ada $(21+7+5)=33$ stasiun. Lokasi stasiun yang mencatat HBMaks pada kelas tersebut tersebar acak di dalam wilayah UPT. 


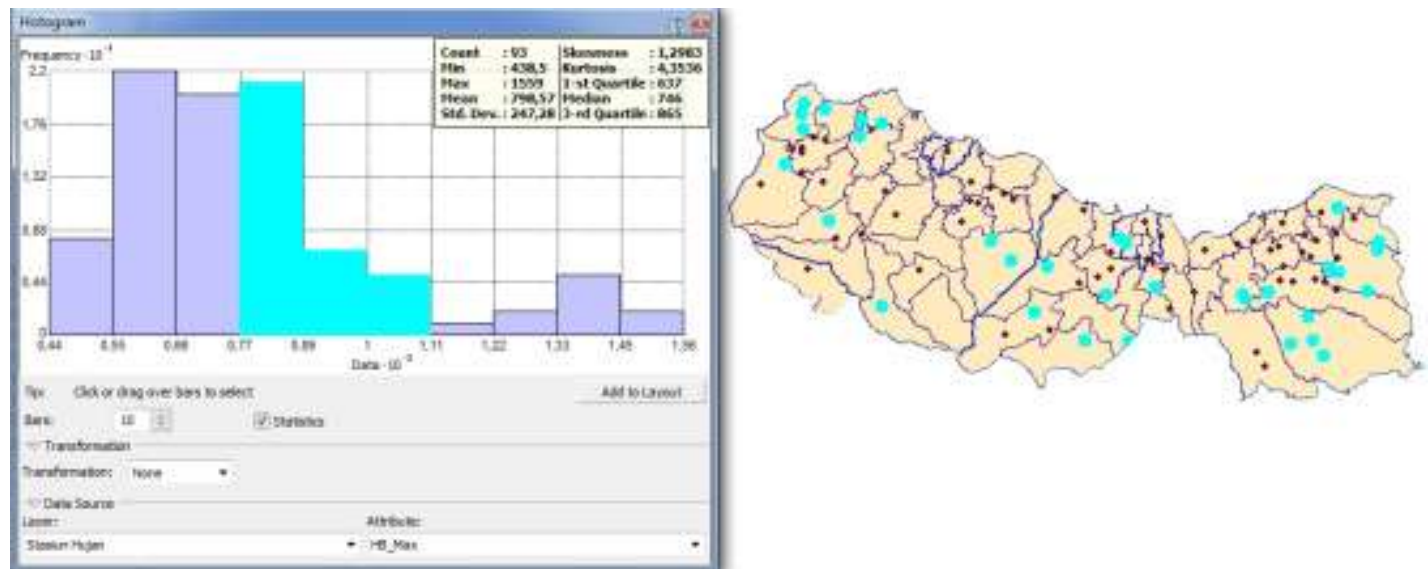

Gambar 15. Distribusi Frekuensi dan Sebaran Spasial Stasiun Hujan yang Mencatat Nilai HBMaks antara $770-1111 \mathrm{~mm} / \mathrm{bulan}$

Selanjutnya, Gambar 16 menampilkan distribusi frekuensi (kiri) dan sebaran spasial (kanan) stasiun hujan yang mencatat nilai HBMaks sangat ekstrem (antara $1111-1560$ $\mathrm{mm} / \mathrm{bulan})$ sepanjang periode 36 tahun. Terlihat, hanya ada $(1+2+5+3)=10$ stasiun hujan. Lokasi stasiun tersebar di beberapa wilayah di bagian tengah-timur dan selatan-barat dari wilayah UPT.
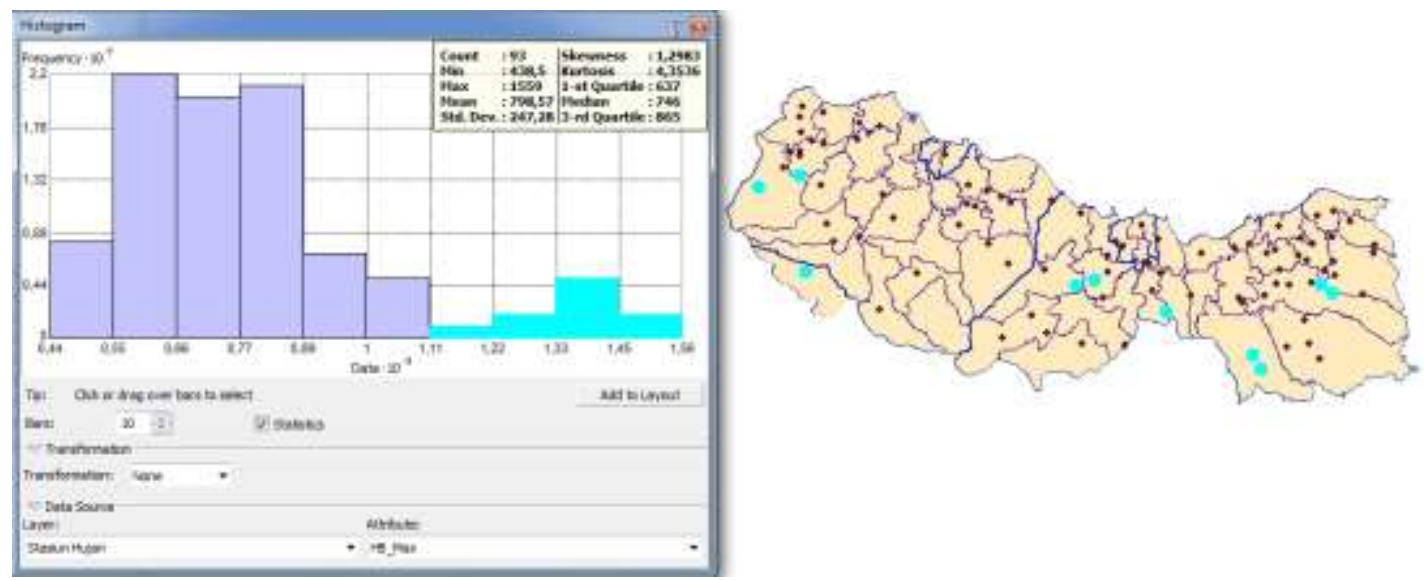

Gambar 16. Histogram Distribusi Frekuensi dan Sebaran Spasial, Stasiun Hujan yang Mencatat Nilai HBMaks antara $1111-1560 \mathrm{~mm} /$ bulan.

Histogram distribusi frekuensi dan peta sebaran spasial loksi stasiun hujan sebagaimana diuraikan pada point sebelumnya, dapat memperlihatkan fungsi histogram untuk menggambarkan variabilitas spasial hujan bulanan rerata (HBR) dan hujan bulanan maksimal (HBMaks). Pola sebaran HBR relatif sejalan dengan pola ketinggian yang ada di wilayah tersebut. Sebaran lokasi stasiun dengan pencatatatn HBMaks cendrung acak dan tidak mengikuti ketinggian tempat. HBmaks lebih bersifat lokal.

\section{c. Interpolasi: Peta Hujan Bulanan}

Pada penelitian ini, metode interpolasi IDW (Inverse Distance Weigthing) (Johnston et al., 2001) digunakan untuk membuat peta tematik melalui interpolasi nilai HBR dan HBMaks dari ke 93 lokasi stasiun hujan dalam tersebut. Pemilihan metode interpolasi IDW didasarkan pada penelitian sebelumnya (Indarto, 2011, Indarto, 2013ab). Gambar 17 dan 18 menampilkan hasil interpolasi IDW untuk variabel HBR. Interpolasi menggunakan IDW dengan parameter power $\left(1 / \mathrm{d}^{2}\right)$. 


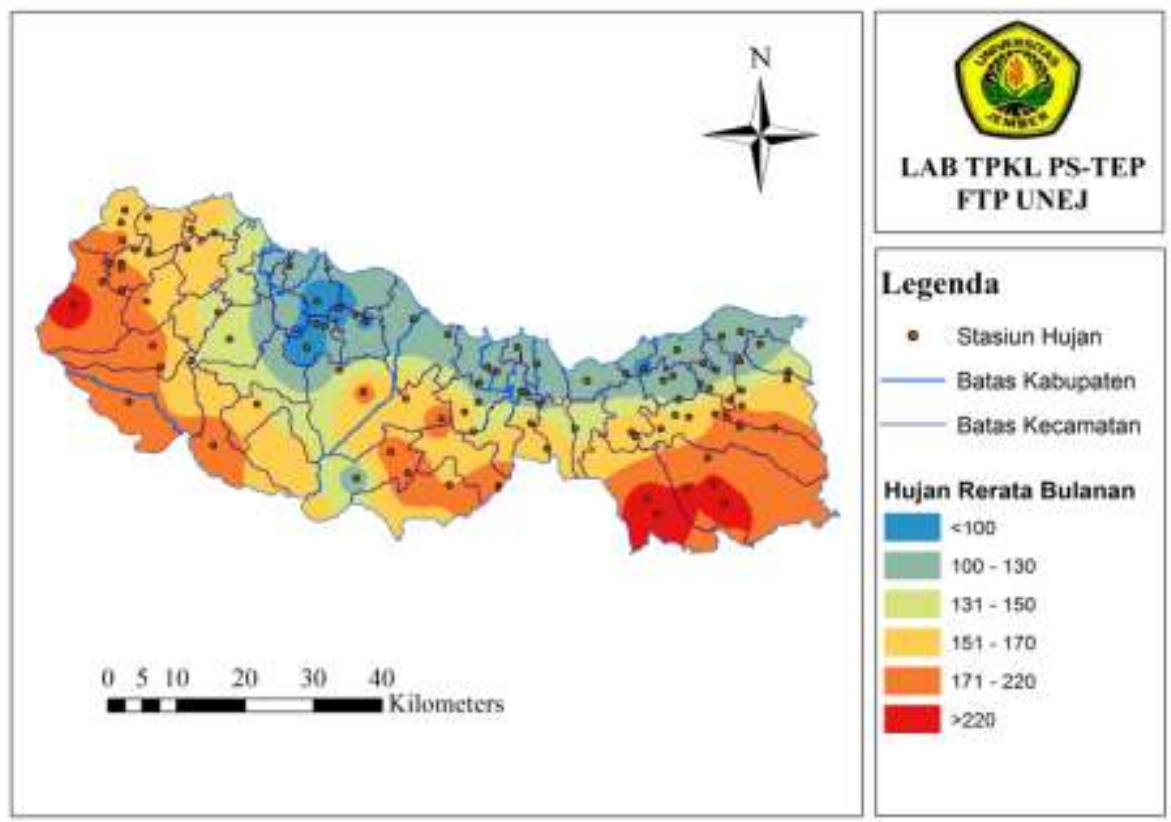

Gambar 17. Peta Distribusi Spasial Hujan Rerata Bulanan (HRB) Wilayah UPT PSDA Pasuruan, Selama periode $1980-2015$.

HBR diklasifikasikan ke dalam 6 kelas, dengan tiga kategori. Kategori HBR rendah untuk $<150 \mathrm{~mm} /$ bulan, HBR sedang antara $150 \mathrm{~mm} /$ bulan sampai dengan $220 \mathrm{~mm} /$ bulan, dan HBR tinggi pada kelas HBR $>220 \mathrm{~mm} / \mathrm{bulan}$.

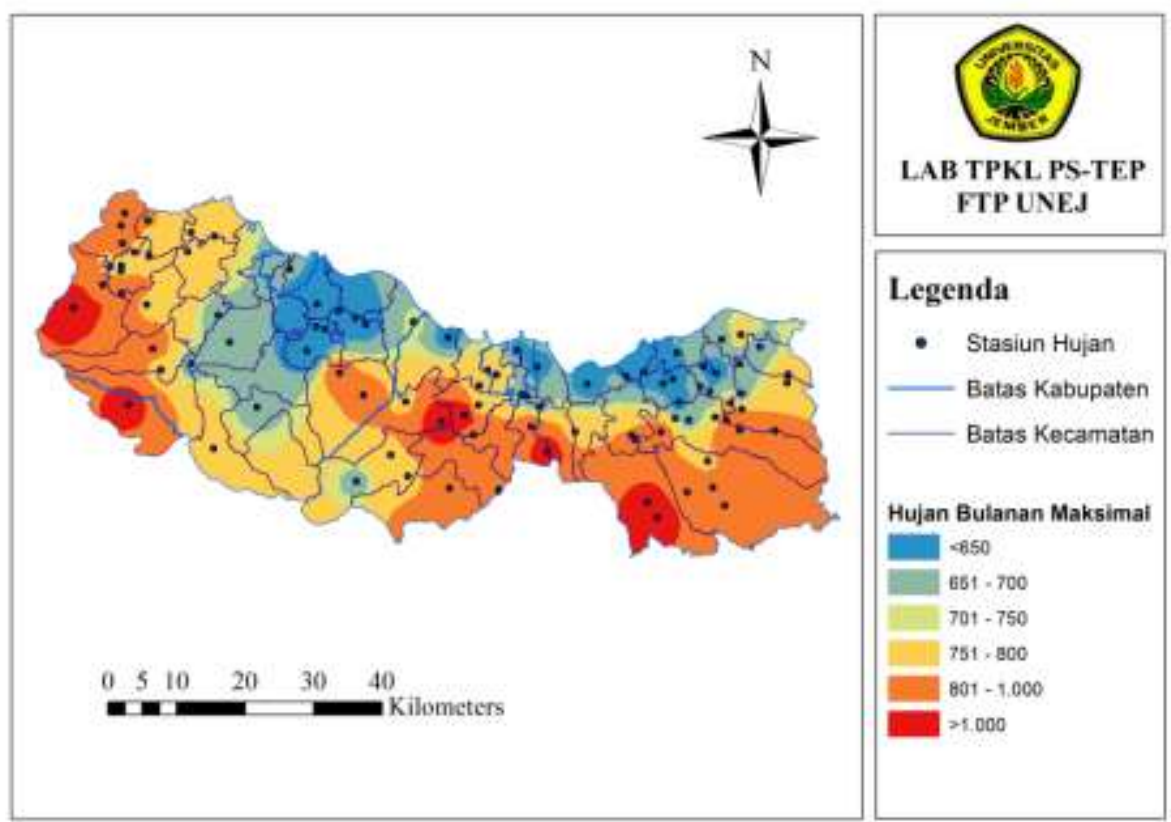

Gambar 18. Peta Distribusi Spasial Hujan Bulanan Maksimal (HBMaks) di Wilayah UPT PSDA Pasuruan, Selama Periode 1980 - 2015.

Gambar 18 menunjukkan distibusi spasial hujan bulanan maksimal (HBMaks) yang terjadi di wilayah UPT, selam periode rekaman hujan dari $1980 \mathrm{sd} 2015$. Pola sebaran HBMaks lebih bersifat lokal dripada HBR. Hal ini karen sifat dari hujan maksimal yang terjadi sangat lokal. 


\section{KESIMPULAN}

Analisis variabilitas temporal dan spasial hujan bulanan rerata (HBR) dan hujan bulanan maksimal (HBmaks) telah dilakukan di wilayah UPT PSDA di Pasuruan. Data hujan harian dari 93 stasiun hujan yang tersebar di seluruh UPT PSDA Pasuruan digunakan sebagai input utama. HBR dan HBmaks didapat dari penjumlahan data hujan harian. Analisis variabilitas temporal dan spasial per sub-wilayah dilakukan menggunakan tool Histogram. Peta tematik HBR dan HBMaks dibuat menggunakan metode interpolasi IDW. Hasil penelitian ini menunjukkan bahwa Histogram dapat menggambarkan variabilitas temporal dan spasial hujan per sub-wilayah dengan lebih detail. Peta tematik hasil interpolasi menunjukkan variabilitas spasial HRB antara $<100 \mathrm{~mm} /$ bulan hingga $>220 \mathrm{~mm} /$ bulan dan HBMaks antara $<650$ $\mathrm{mm} / \mathrm{bulan}$ sampai dengan $>1.000 \mathrm{~mm} / \mathrm{bulan}$.

\section{UCAPAN TERIMA KASIH}

Penelitian ini merupakan bagian dari Penelitian Hibah Kompetensi - DRPM tahun anggran 2016-2017. Ucapan terima kasih disampaikan kepada DRPM kementrian RisetDIKTI yang telah mendanai penelitian ini melalui Program HIBAH Komptensi dan kepada semua pihak yang telah membantu terlaksananya penelitian ini.

\section{DAFTAR PUSTAKA}

Indarto dan Boedi S. 2011. Variabilitas Spasial Hujan Tahunan di Jawa Timur: Aplikasi ESDA (Histogram, Voronoi Map, QQ-Plot, Trend Analysis). Jurnal Teknik Sipil, Vol. XI ISSN 1412 - $0976: 61$ - 69. [25 Agustus 2017]

Indarto. 2013a. Analisis Geostatistik. Yogyakarta: Graha Ilmu.

Indarto. 2013b. Variabilitas Spasial Hujan Harian di Jawa Timur. Jurnal Teknik Sipil, Vol. 20(2) : 107-120. [25 Agustus 2017]

Johnston, K., Ver Hoef, J.M., Krivoruchko, K. dan Lucas, N. 2001. Using ArcGIS Geostatistical Analyst. GIS by ESRI. 